\title{
HIPK2 wt Allele
}

National Cancer Institute

\section{Source}

National Cancer Institute. HIPK2 wt Allele. NCI Thesaurus. Code C102957.

Human HIPK2 wild-type allele is located within 7q32-q34 and is approximately $231 \mathrm{~kb}$ in length. This allele, which encodes homeodomain-interacting protein kinase 2 protein, is involved in serine/threonine phosphorylation, cell cycle regulation and apoptosis. 